\title{
PÕHIMÕTtELISELT VÕI PRAKTILISELT PAIDES - KAHE SARNASE FUNKTSIOONIGA SÕNA KÄEKÄIGUST
}

\author{
Annika Küngas
}

Ülevaade. Artikkel analüüsib sõnade põhimõtteliselt ja praktiliselt kasutust eesti kirjakeele korpuse andmete põhjal, lähtudes ennekõike semantikast ja pragmaatikast, kuid ka süntaksist ja foneetikast. Keskendutakse viimase kahe sajandi materjalile, kuna oma tänapäevasel kujul ilmnesid põhimõtteliselt ja praktiliselt esmakordselt 20. sajandi esimesel poolel. Sõltuvalt kontekstist võivad need sõnad funktsioneerida mitmel viisil. Adverbilises kasutuses on põhimõtteliselt ja praktiliselt üksused, mille leksikaalne väli ei kattu. Siiski on nendele sõnadele lisandunud uusi tarvitusi, mille sarnasus on hõlpsasti tajutav, nt kui neid pruugitakse umbmäärastavas funktsioonis või diskursuseülese üksusena.

Võtmesõnad: pragmaatilised markerid, määrsõnad, kirjalik keel, korpusuuringud, eesti keel

\section{Sissejuhatus}

Artiklis võetakse vaatluse alla kahe sõna, põhimõtteliselt ja praktiliselt kasutusmuster, eesmärgiks on jälgida korpuseandmete põhjal nende üksuste funktsioonide arengut. Näidatakse, et põhimõtteliselt ja praktiliselt esindavad polüseemiat, mille uurimine annab aimu keelest ja keele muutumise seaduspäradest üldisemalt. Seega on uuritavate sõnade puhul tähtis, et neid on kasutatud erinevates funktsioonides. Üksused esinevad tänapäeval nii adverbide kui ka pragmaatiliste markeritena, jagunedes pragmaatilises kasutuses omakorda modaalpartikliteks ja diskursusemarkeriteks. ${ }^{1}$ Ulatuslik ülevaade eri autorite pragmaatiliste markerite käsitlustest on esitatud siinkirjutaja varasemas artiklis (Valdmets 2013: 110-112). Selle kirjatöö sisu siin dubleerima ei hakata, kuid tuuakse välja tähtsamad pidepunktid adverbide

Märäsõna, adverb ja täistähenduslik viitavad artiklis autosemantilisele üksusele ning (pragmaatiline) marker, 
grammatisatsiooni kohta. Artiklis toetutakse grammatisatsiooni seletamisel mudelile (Hopper 1991), mille järgi keelendi A grammatiseerumine mingis kontekstis algab tähendusnihkega. Seejärel saab keelend uue kasutusmustri B. Kolmandas (eeldatavas) staadiumis jääb kasutusse vaid B, A taandub. Küll aga on tõdetud, et kõik keelendid ei jõuagi tsükli kolmandale astmele.

Kuigi siin vaadeldavate sõnade esmane kasutus eesti keeles on täistähenduslik (vt nt EKSS), on neile grammatiseerudes lisandunud pragmaatilisi nüansse, mis on selgesti märgatavad just viimaste aastakümnete keeletarvituses. Nii on adverbidest kujunemas pragmaatilised markerid (vt nt Fraser 1996, Traugott, Dasher 2002, Brinton, Traugott 2005). Erinevalt adverbidest ei osale pragmaatilised markerid propositsiooni väljendamisel, pigem ilmneb nende funktsioon kindlas kontekstis. Pragmaatilisi markereid on keeleteaduslikus kirjanduses defineeritud eri vaatenurkadest. Siinkohal on peamiselt tuginetud Laurel J. Brintoni (1996) käsitlusele: need on raskesti määratletavad üksused, mida kasutatakse keeles erinevates pragmaatilistes funktsioonides, kusjuures nende algne adverbiline ülesanne on ajapikku hääbumas. Pragmaatilisi markereid võib omakorda jagada modaalpartikliteks ning diskursusemarkeriteks (Traugott, Dasher 2002, Valdmets 2013), kusjuures kahe kategooria eristamine võib olla problemaatiline (Traugott 2007: 141). Modaalpartikliteks loetakse üldjuhul sõnad, mis funktsioneerivad fraasi-või lauselaiendina (Valdmets, Habicht 2013). Diskursusemarkerite rühma kuuluvad üksused, mis on vaid marginaalselt modaalsed (vt analüüsi Traugott, Dasher 2002: $152 \mathrm{jj}$ ), pigem on need suurema mõjualaga kui lause, sidudes teksti osi ja luues tervikut (vt täpsemalt ka Valdmets 2013). Diskursusemarkerid asetuvad enamasti lausealgulisse positsiooni, kuid ei seostu muu lausega. Nii on nende ülesandeks tihtipeale kõnes vooruvahetuse hõlbustamine ja kirjas lõikude markeerimine. (Brinton 1996: 6)

Toetudes nii üldistele kui ka partikleid puudutavatele grammatisatsioonikäsitlustele (Brinton 2010, Traugott, Dasher 2002, Heine 2002, Heine, Narrog 2010 jt), võib märgata, kuidas täistähenduslikud adverbid grammatiseeruvad ajapikku pragmaatilisteks üksusteks. Eespool esitatud kolmeastmelise grammatisatsioonimudeli (Hopper 1991) mõistetes on lt-liitelised sõnad jõudnud protsessi teise järku. Uues funktsioonis keelendid ei ole enam sisult nii läbipaistvad kui nende adverbiline lähe. Üldist muutumismustrit arvesse võttes võime eeldada, et põhimõtteliselt ja praktiliselt on kujunemisjärgus üksused, mille kasutus varieerub, ja seega on võimalik küsida, kas ja missugustes kontekstides nad on muutumas adverbist pragmaatiliseks markeriks.

\section{Analüüsi lähtekohti}

Eeltoodust nähtub, et sellistel üksustel võib tänapäeval olla nii adverbiline (1a), (1b) kui ka pragmaatiline (2a), (2b) kasutus.

(1a) Ta on juba põhimõtteliselt igasuguse propaganda vastane.

(1b) Ma tunnen oma tööd nii teoreetiliselt kui ka praktiliselt.

(2a) Tal põhimõtteliselt puudub kontakt välismaailmaga.

(2b) Praktiliselt pool saalisviibijatest on mehed. 
Nimetatud üksuste ühe kasutusvõimalusena tõuseb esile võrdsussuhte neutraalse ligikaudsuse väljendamine (vt ka Erelt 1986: 105). Näiteis (2a), (2b) on sõnad põhimõtteliselt ja praktiliselt oma täistähenduslikust kasutusest nihkunud ning nende sünonüümideks on saanud umbmäärased hulgasõnad umbes, peaaegu, enam-vähem, üsna jm. Samasse rühma kuuluvad veel mõned teisedki kirjakeeles laialdaselt kasutatavad sõnad (nagu suhteliselt). Põhimõtteliselt ja praktiliselt on siinsesse artiklisse valitud kui tüüpnäited, mis esindavad ka teisi samalaadseid rõhusõnu. Randolph Quirk jt (1985: 445) on välja toonud intensiivsussõnad (ingl intensifiers), jagades need kaheks: võimendajad (amplifiers; eesti keeles nt kohutavalt hägune, täielikult naeruväärne) ja pehmendajaid (downtoners; nt peaaegu võimatu, üsna normaalne, natuke igav). Douglas Biber jt (1999: 554-555) on neid gruppe nimetanud vastavalt intensifiers ja diminishers. Nagu eesti keeleski, võib ingliskeelsetes näidetes leida võimendajate ja pehmendajatega samakujulisi üksusi, mida täistähenduslikus kasutuses pruugitakse viisimäärsõnana, kuid edasise arengu käigus on märgatavad nihked määratähenduse poole, seda eriti modaalsete fraasilaiendite puhul. Pehmendajad on mõnes kontekstis kasutusel ka selleks, et mahendada lausega väljendatut, et ei tekiks konflikti kõneleja ning vastuvõtja vahel (vt ka Aijmer 2013). Siinkohal on mh võimalik leida paralleele lauselaiendilise kasutusega.

lt-sõnade pragmaatilist kasutust jälgides jäävad silma nii mõnedki keelendid, mis laiendavad omadussõnu, paiknedes omadussõnafraasis vahetult enne peasõna. Siin käsitletavad kaks üksust on valitud just seetõttu, et mõlemal on selline kasutus võimalik. Nende kollokatsioonide näol on enamasti tegu fraasidega, mille alistusseoses olev liige iseloomustab mingit omadust täpsemalt. Laiendav funktsioon on seotud n-ö tavaliste määralaienditega, ometi erinevad uuritavad muutumatud sõnad selle poolest, et mõnel juhul on nende tähendus nihkunud. Teatud kontekstis on küll võimalik tõlgendada nende (määra/täis)tähendust, kuid enamasti on lisandunud pragmaatiline varjund, mida algtähenduses polnud. Sageli on määratletav sildkontekst (Heine 2002: 86), mis kajastab vaheetappi teel rohkem grammatiseerunud üksuse poole.

Lisaks siin käsitletavatele sõnadele praktiliselt ja põhimõtteliselt käituvad sarnaselt veel näiteks partiklid suhteliselt (suhteliselt tavaline päev), hullult (hullult hea film), häbematult (häbematult kallis korter), sügavalt (mul on sügavalt savi). Toimetamata ning kõnekeelelähedases kirjakeeles leidub ka juba lühenenud üksusi, näiteks absull (absoluutselt), suht (suhteliselt): absull null, suht igav. Lähtutakse eeldusest, et üksus on teisenenud, kui tüve algne tähendus (nt häbematult 'jultunult, häbitult', hullult 'vaimuhaigele kohaselt' või sügavalt 'pinnast allapoole ulatuvalt') ei ole enam täielikult läbipaistev. Kõigil neil sõnadel on lisaks määratähendusele muidugi ka muid funktsioone (rõhutav, kinnitav, pehmendav vms).

Kõike eelnevat arvesse võttes võib modaalpartikleid defineerida kui lauses üldlaiendina toimivaid sõnu, mis lisavad väljendatule modaalse varjundi. Need saavad olla nt episteemilised (vahel ka evidentsiaalsed) või emfaatilised üksused, kusjuures siinses artiklis käsitletud sõnadel võib modaalpartiklina ilmneda veel pehmendav lisafunktsioon. Lauses võrdlemisi vabalt liikuvad fakultatiivsed üksused lisavad öeldule subjektiivse varjundi ja tihtipeale on neile raske omistada mingit konkreetset tähendust. Seega on fraasi- ja lauselaienditeks määratletavad keelendid mitmekülgsed, kuna nende funktsioon ilmneb tihtipeale alles konkreetses kontekstis. 
Näidetes (2a), (2b) on vaadeldavate sõnade semantika juba nihkunud, kuid süntaktiliselt on nad veel lausega seotud. Sellised kasutused üldlaiendina võiks lugeda vähem grammatiseerunuks kui mõned muud pragmaatiliste sõnade näited (vt allpool), millel on võime tekstis vabalt ümber paikneda. Kaugemale grammatiseerunud üksuste alla kuuluvad mh diskursusemarkerid, mis ei muuda lause tavaehitust (adverbi ja markeri eristamise testi kohta vt Aijmer 1997: 4 jj). Siinkohal on paslik vaadata eristamise võimalust eesti keele puhul. Teadupärast paikneb eesti kirjakeele iseseisvas jaatavas väitlauses verb teisel kohal. Mööndustega on võimalik verbi asetada ka muusse positsiooni, kuid enamasti on sellisel juhul märgatav kohmakam lauseehitus. Nimelt on Kaja Taela (1988) andmeil SVX- ja XVS-sõnajärg eesti kirjakeeles sagedaim, moodustades umbes poole kõigist juhtudest. Suulises kõnes (ja tõenäoliselt ka toimetamata kirjakeeles) võib olukord olla teistsugune, Liina Lindström (2005) on näidanud, kuidas suulises kõnes on sagedaim SVX- ja SV-sõnajärg. Seega on mõlema töö põhjal võimalik väita, et eesti keele põhisõnajärjes on enamasti verb teisel kohal. Samale järeldusele on jõutud teisteski uurimustes, vt nt Annekatrin Kaivapalu psühholingvistilise tajutesti põhjal (2010) ning Tuomas Huumo (1995) eesti ja soome keelt võrreldes. On välja toodud mitmesuguseid sõnajärje valiku tegureid infostruktuurist kuni lausetüübini. SVXja XVS-sõnajärjes esineb adverb X-positsioonil. Siinses uurimuses tuuakse muuhulgas välja, et XSV-järg on adverbide puhul ebaloomulikum. Kui laiendada siinset sõnajärjemalli perifeeriate ${ }^{2}$ käsitlusega, kus vasak perifeeria omistatakse tihtipeale just lauset alustavatele diskursusemarkeritele (Hansen 1997: 156, Schourup 1999: 233), siis järjend lt-sõna-subjekt-verb (sõna topikaliseeritakse ilma subjekti ja verbi inversioonita) võiks mõnes kontekstis viidata just pragmaatilisele kasutusele. Diskursusemarkereid käsitatakse kui grammatiseerunud üksusi, mille lisamisel lause algusesse ülejäänud lause ehitus ei muutu.

Võrdleme kaht lauset, kus sõna põhimõtteliselt võib lugeda pragmaatiliseks markeriks. Mõlemas lauses on sõna semantilis-pragmaatiline tähendus muutunud, kuid lausete erinevus seisneb sõnajärjes. Nimelt näites (3) toimub sõna põhimõtteliselt järel aluse ja öeldise inversioon, kuid näites (4) mitte. Siinkohal on põhimõtteliselt näites (4) loetud rohkem grammatiseerunud diskursusemarkeriks, sest see on lisatud konteksti nii, et lause põhistruktuur ei muutu ning sõna põhimõtteliselt väljajätt ei muudaks lauset (4) ebaharilikuks.

(3) Minul küll hämaras esinemisega probleeme pole. Põhimõtteliselt oskan ma klaverit mängida ka kinnisilmi.

(4) Minul küll hämaras esinemisega probleeme pole. Põhimõtteliselt ma oskan klaverit mängida ka kinnisilmi.

Diskursusemarkerid on niisiis sõnad, mis struktureerivad diskursust. Modaalpartiklitega sarnaselt on need semantiliselt raskesti määratlevad üksused. Diskursusemarkerid toimivad aga pigem lauseüleselt kui lausesiseselt. Nad paiknevad tavaliselt lause alguses (vahel ka lõpus), seostades eri lauseid omavahel, et tekiks koherentne diskursus. On väidetud, et sellised ülejäänud lausega nõrgalt seotud üksused, mille tähendust on keeruline defineerida, pole samas kontekstis vahetatavad (Schourup 1999: 242-243): nende kommunikatiivne funktsioon võib olla sootuks erinev. Seega on need kontekstisidusad sõnad. Siinkohal on märkimisväärne, 
et põhimõtteliselt ja praktiliselt on vähemalt oma modaalpartiklilises tarvituses sarnased, st vahetatavad.

Järgnevalt ongi vaadatud uuritavate sõnade semantilis-pragmaatilist külge ning põgusalt ka süntaksit (adverbide ja pragmaatiliste markerite tunnusjoonte loetelu vt Valdmets 2013: 126). Keeleüksuste arengu liikumapanevaks jõuks on tähendusnihe, seetõttu on esmalt kirjeldatud sõnade tähendust ning vaadeldud kasutusvõimalusi. Nii on täheldatud (Valdmets 2013), et adverbid kannavad konkreetset sisu ja neid on võimalik küsimustada, samal ajal kui markerid on abstraktsed küsimustamatud üksused. Määrsõnad on kontekstist sõltumatud, kuid pragmaatilised markerid võivad olla lauseümbrusega seotud (omandadeski tihtipeale tähenduse konkreetses ümbruses). lt-sõnad võivad lause propositsioonis osaleda (adverbid) või sellest välja jääda (markerid). Lisaks semantikale ja pragmaatikale on uuritavate sõnade puhul määrav ka süntaktiline käitumine. Adverbid on seotud üksused, samal ajal kui pragmaatilised markerid on süntaktiliselt enamasti nõrgalt seotud. Adverbidele, kuid mitte pragmaatilistele markeritele, on omane võime siduda laiendeid ja esineda lauseliikmena. Lisades siia ka foneetilise tasandi, võib märkida, et ennekõike pragmaatilise markeri funktsioonis on võimalik selliste üksuste lühenemine.

Artikli materjal pärineb Tartu Ülikooli eesti kirjakeele korpusest ja tasakaalus korpusest. Peamiselt on vaatluse all toimetatud ilukirjanduslikud ja ajakirjanduslikud tekstid, kuid kasutatud on ka toimetamata kirjakeele näiteid (uue meedia allkorpusest). Uuritav ajavahemik ulatub sõnade esimestest kasutusjuhtudest korpuses kuni praeguseni. Põhimõtteliselt ja praktiliselt oma tänapäevasel kujul vana kirjakeele korpuses ei esine. Küll on aga vanematest tekstidest võimalik leida nende sõnade tüvesid (sellekohased viited esitatakse edaspidi vastavate alapeatükkide juures). Siinne uurimus on ennekõike kvalitatiivne vaatlus nende sõnade kujunemisest ja kasutusest. Kvantitatiivsed andmed kirjakeele korpuse aja- ja ilukirjanduslike tekstide kohta esitatakse vaid taustinformatsioonina, kasutades andmeid siinkirjutaja magistritööst (Valdmets 2010).

\section{Põhimõtteliselt}

Põhimõtteliselt on sõna, mis adjektiivist põhimõtteline tuletatuna kannab tähendust 'põhimõttekindlalt', 'põhimõtteisse puutuvalt', 'põhimõtte pärast' ja 'printsipiaalselt'. Vana kirjakeele korpuses nimetatud sõnakujusid ei esine, küll aga annavad vanad tekstid aimu selle liitsõna arengust. Nii leidub Heinrich Gösekeni grammatikas ja sõnastikus lihtsõna pohhi (aastast 1660, siin kasutatud Kingisepa jt 2010. aasta uustrükki) ning Anton Thor Hellel pohhi ja mõtlik, mõtte (aastast 1732, siin kasutatud Kilgi ja Rossi 2006. aasta uustrükki).

Põhimõtteliselt ilmneb oma tänapäevasel kujul esmakordselt 1930. aastate tekstides. Vanemast keelest (1890.-1910. aastate korpusest) on leitavad ka tänapäevasest erineva täiendsõnakujuga vormid nagu põhjusmõttelikult ja põhjusmõtteliselt (5). Hiljem saab valdavaks tänapäeval tuntud vorm.

(5) Põhjusmõttelißelt ei olnud wiimaßel küll mitte eeßtwõtja koha wastu midagi, aga tegelißelt ßeda enam. (ILU1910) 
Sõna põhimõtteliselt esinemissagedus on kuni 1990. aastateni väga madal, umbes kümmekond tarvitusjuhtu ühe aastakümne tekstides (täpseid arvandmeid vt Valdmets 2010: 44). Viimastel aastakümnetel on sõna kasutus suurenenud, 1990. aastate tekstides ulatub kasutus üle poolesaja juhu, 2000. aastatel on see muuhulgas korpuse mahu suurenemise tõttu sagedam kui kogu 20. sajandi peale kokku. Ka normaliseeritud andmeid vaadates on võimalik märgata ühtlast kasutussageduse kasvu (Valdmets 2010: 75). ${ }^{3}$ Tõdedes, et keelendi sage kasutamine annab eelduse selle grammatisatsiooniks (Bybee 2003, Hopper 1998: 156-159), on lähtekoht uurimuseks olemas. Konkreetseid arvandmeid on siin kasutatud vaid taustinformatsioonina, keskendudes pigem sõnade kvalitatiivsele analüüsile.

Näites (6) on näidatud adverbiline kasutus, millele viitavad nii tähendus ('põhimõtte poolest'), positsioon lauses kui ka rõhusõna (juba).

(6) Kärusid oli nelja liiki - eesli-, härja-, traktori- ja inimkärud, kusjuures viimased erinesid esimesest juba põhimõtteliselt. (OR2002)

Olgu siinkohal toodud ka teine näide adverbilisest kasutusest (7), kus konkreetne tähendus ilmneb ümbritsevast kontekstist. Siinses näites kannab põhimõtteliselt tähendust 'põhimõtte pärast', kuna autor kirjeldab inimesi, kes on oma põhimõtetelt vägivallavastased.

Teades, et uuritaval üksusel on eesti keeles ka teine, laiendav funktsioon, võiks põhimõtteliselt siinses lauses olla analüüsitav ka iga laiendina, kollokatsioonis põhimõtteliselt iga 'peaaegu iga'. Selline tõlgendus pole aga väga tõenäoline ümbritsevat konteksti arvesse võttes. Siinne näide on huvitav veel teiselgi põhjusel: nimelt alustab lauset pragmaatiline marker muidugi, mis on iseseisva üksusena ülejäänud tekstist komaga eraldatud.

(7) Muidugi, need, kes põhimõtteliselt iga vägivalla vastu räägivad, ei tea, mis nad räägivad. (ILU1938)

Edaspidi on toodud näited, kus uuritava sõna funktsioon liigub adverbilisest kasutusest pragmaatilise suunas. Funktsioonimuutus on enim märgatav kontekstides, kus sõna põhimõtteliselt algne tähendus ei ole enam võimalik, selle kui pragmaatilise markeri sünonüümiks võivad olla peaaegu, üldiselt jmt. Põhimõtteliselt pragmaatiline tähendus ilmneb selgelt siis, kui tekib semantiline vastuolu, nagu on märgata lauses (8).

(8) Peab kohe ütlema, et Vahemere kultuuriruumis pole selles põhimõtteliselt midagi skandaalset (peaasi on säilitada macho hoiak), kuid tema balansseeris siiski skandaali piiril. (ET2002)

Siin modifitseerib põhimõtteliselt pronoomenit miski, kuid sage on see ka koos näitava omadussõnalise asesõnaga, nt sama või samasugune (põhimõtteliselt sama esines nt Eesti Päevalehe 2007. aasta kogus viies lauses, kokku kasutati sõna põhimõtteliselt selle aastakäigu tekstides 101 korral). Fraas põhimõtteliselt midagi on siinkohal välja toodud, kuna ilmneb huvitav asümmeetriline kollokatsioon: seda fraasi kasutatakse eitavas lauses sagedasti, kuid juhtumit, kus pronoomen miski oleks nominatiivis ja kasutusel jaatavas lauses (*põhimõtteliselt miski), korpuses ei leidu. Lauses (8) on põhimõtteliselt fraasilaiend ning see on süntaktiliselt seotud

3 Sõna põhimõtteliselt kasutussagedus 100000 korpuse sõna kohta on esimesel esinemisel kirjakeele korpuses (1930. aastatel) 1,08; 2000. aastatel on see tõusnud 4,54 sõnani (Valdmets 2010: 120). 
üksus. Samal ajal on aga sõna semantiline kese nihkunud uue kasutuse suunas ning üksus on kaotanud võime paikneda lauses rõhulises positsioonis. Sellise olukorra tingib keeles toimuv pidev protsess, kus konkreetse üksusega liituvad lisatähendused. Lõpuks pääseb mõjule lisatähendus, millest saab mingis kontekstis sõna uus semantiline kese. Põhimõtteliselt näites (8) on loetud modaalpartiklite hulka, mis pole küll täielikult oma funktsiooni muutnud, kuid on grammatiseerumas.

Lauses (9) esineb pragmaatiline marker dialoogis vastusena koos sõnaga ei. See funktsioneerib episteemilise partiklina, mis pehmendab öeldut ning väljendab kõneleja ebakindlust, vältides konkreetset eitavat vastust küsimusele. Toodud on ilmekas näide selle kohta, et teatud olukordades võib ka modaalpartikkel esineda lausealguselises positsioonis. Kõneleja on otsustanud otsekohesuse vältimiseks kasutada modaalsõna põhimõtteliselt, selle asemel et vastata konkreetse eitusega. Sama partiklit oleks saanud kasutada ka jaatava konstruktsiooni puhul (põhimõtteliselt jah / põhimõtteliselt küll). Põhimõtteliselt võib olla partiklina ka üksikliikmena üldküsimuse vastuseks. Kui aga sõna kasutatakse eriküsilausele vastamiseks (nt kui küsimus algab sõnaga kuidas), siis funktsioneerib põhimõtteliselt eranditult adverbina. Näitega (9) sarnast kasutust on võimalik leida ka praktiliselt puhul, vt lauset (21) allpool.

(9) - Kas te ei ole ühessegi oma töösse siiamaani armunud?

- Põhimõtteliselt ei. Ma tahan ikka ja jälle uut, uut ja uut. (AJA1990)

Lauses (10) on sõnal pehmendav funktsioon ning põhimõtteliselt liigub modaalpartikli ja diskursusemarkeri äärealal, kuid kuulub sellegipoolest pragmaatiliste markerite hulka.

(10) fun|tegeleb: a lincy|s2tib millal sa liikuma saad hakata? [---] lincy|s2tib: kle kohe põhimõtteliselt (JT)

Kasutades sõna põhimõtteliselt, võtab kõneleja tagasi öeldu sirgjoonelisust. Jututoa kasutaja lincy|s2tib ütleb alguses, et ta hakkab kohe liikuma, kuid seejärel lisab partikli põhimõtteliselt näitamaks, et ta sel konkreetsel hetkel siiski ei stardi. Modaalpartikkel põhimõtteliselt on lauses (10) järelasendis, mis reaalajas toimuvas suhtluses on tihtipeale kasutusel seisukohavõtu markeerimiseks (Keevallik 2003: 74-76, sh arutlus markeri ma arvan kohta). Reaalajas toimuvas suhtluses, nt telefoni- või jututoavestluses, lisatakse väitele tihtipeale pehmendus, mis vähendab väite jõulisust ning muudab fakti vähem kindlaks. Näites (10) väldib jututoa külaline lincy|s2tib partikli põhimõtteliselt abil otsekohesust ja seetõttu on võimalik tuua funktsionaalne paralleel ka järelasendis kasutatud episteemilise üksusega ma arvan.

Lauses (11) on aga esile kerkimas uus, diskursusefunktsioon: põhimõtteliselt märgib muutust diskursuses. Nimelt on see analüüsitav sõnana, mis ei funktsioneeri üldlaiendina, vaid pigem on sellel lauseteülene haare. Seega on üksus interpreteeritav diskursusemarkeriks, mida iseloomustab vaid marginaalne modaalsus ja esile on kerkinud uus, infot siduv või laiendav funktsioon. Täielikult väljakujunenud juhul on diskursusemarker lisatud lause algusesse nii, et see ei muuda järgneva lause ülesehitust. Diskursusemarker on üksus, mis ühildab eelnevalt väljendatut järgnevaga. 
(11) Esiteks on neis riietes palav. Teiseks on need kleidid nii pikad, võimatu on graatsiliselt kõndida. Põhimõtteliselt koperdan ja komistan ma iga sekundi tagant. (KR2003)

Näites (11) on põhimõtteliselt lausega süntaktiliselt seotud, kuna uuritavale sõnale järgneb verb ning sellele subjektpronoomen $m a$ (eeldades tavapärast jaatava lause SV-sõnajärge; sõnajärje kohta vt ka Aijmer 1997). Seega võib öelda, et uuritaval sõnal on veel ühiseid jooni adverbilise kasutusega, kuna sõna põhimõtteliselt oleks raske tekstist välja jätta: see on seotud üksus, mille eemaldamine tekitaks lauses vastuvõetamatu sõnajärje (Teiseks on need kleidid nii pikad, võimatu on graatsiliselt kõndida. * Koperdan ja komistan ma iga sekundi tagant.). Sõna algtähendus on aga kadunud ning esile on kerkinud uus interpreteerimisvõimalus: sõnaga põhimõtteliselt näitlikustatakse seda, mis on ebagraatsiline kõndimine. Seda võib pidada nii põhjusseose kui ka selgitava-laiendava funktsiooni kandjaks. Kuigi diskursusemarkerid üldjuhul modaalsust ei kanna, on nendel siiski aeg-ajalt marginaalne modaalsus hoomatav. Nii ka ülaltoodud näites, kuna iga sekundi tagant komistamine on ilmne liialdus.

Järgnevas näites esineb põhimõtteliselt samuti diskursusemarkerina. See ühendab kaht lauset, sidudes eelneva järgnevaga. Sõnal puudub rõhutav funktsioon, kuid märgatav on siduv rakendus.

(12) 15. koha saanud Kirsipuule on tänu võlgu McEwen, kes tema tuulest esimesena finišijoone ületas. "Üritasin oma taktikaga läbi ajada. Põhimõtteliselt see ka õnnestus, kuid kahjuks sattusin grupi ette liiga vara ja viiskümmend meetrit enne lõppu sain kangi. [---]” (EPL2005)

Näites (12) pole põhimõtteliselt lausega süntaktiliselt seotud ning see ei põhjusta ka subjekti ja verbi inversiooni. Seega leidub korpuses kasutusjuhte, kus sõna on juba selgelt oma algsest kasutusest eemaldunud, st arenguteel adverbist pragmaatiliseks markeriks on siin uuritavad üksused partiklistunud. Sõnad on minetanud oma algse ülesande ning neid kasutatakse uutes funktsioonides, nii ka lauses (12), kus autor püüab anda oma tegevusele hinnangut. Alustades teist lauset sõnaga põhimõtteliselt, püüab autor näidata, et tema õnnestumine teatud ettevõtmises ei olnud täielik, kuid siiski valdav. Kasutades sõna põhimõtteliselt, selgitab ja laiendab autor eelöeldut ehk täpsemalt seostab sellega kaht lauset, kuid see, kas tegemist on laiendusega, selgub alles järgnevast hinnangust õnnestumise kohta. Põhimõtteliselt toimib ka siinses näites diskursuse tasandil ning see üksus on võimalik lausest välja jätta. Võrreldes diskursusemarkereid näidetes (11) ja (12) võib märkida, et semantika põhjal otsustades on põhimõtteliselt selgemini markerina kasutusel näites (11), süntaksi põhjal otsustades aga näites (12), kus markeri olemasolu või puudumine ei muuda lause üldist struktuuri. Erinevalt näitest (11) oleks diskursus näites (12) ka ilma sõnata põhimõtteliselt grammatiliselt korrektne: Üritasin oma taktikaga läbi ajada. See ka õnnestus, kuid kahjuks sattusin grupi ette liiga vara ja vïskümmend meetrit enne lõppu sain kangi. Selline sõnajärg mõjuks aga diskursuses ebaloomulikumalt ning kaoks ka hinnangu marginaalne pehmendav interpretatsioon.

Kõnelähedases kirjakeeles on levinud ka lühenenud vormid, mis funktsioneerivad vaid pragmaatiliste markeritena ega esine kunagi täistähenduslikena. Näiteks võib jututubadest, foorumitest jm toimetamata tekstidest leida vorme nagu põhimõtselt, põmst, pmst, pms jne. Järgnevalt on välja toodud kaks näidet korpuse 
jututubadest, kus on kasutatud diskursusemarkereid, mis haakuvad kirjakeele analüüsiga. Põhimõtteliselt (õigemini selle lühenenud vorm) korraldab siinkohal diskursust. Lausetes (13) ja (14) alustavad kasutajad truggy ja modegirl vooru sõnaga põhimõtteliselt, sidudes selle abil eelnevat järgnevaga.

Näites (13) funktsioneerib põhimõtteliselt üksusena, mis alustab summeeriva sõnana vastust eelnevatele voorudele. Siinse pmst kasutuse võib lugeda veel marginaalseks modaalsuse väljendajaks, kuid esmajoones on siiski tegemist diskursusemarkeriga. Kasutajad snow ja kagu küsivad väikese vahega üldjoontes sama küsimuse, millele kasutaja truggy mõlemal korral reageerib. truggy ei vasta küsimusele otse, vaid formuleerib selle ümber, kasutades küsijatega sama verbi. Markeriga pmst annab truggy mõista, et ta ei vasta küsimusele nii, nagu see on esitatud, vaid annab olukorrale oma hinnangu, koondades selle kokkuvõtva sõna pmst järele.

(13) kagu: ainult vaikus

snow: tore

snow: seegi

kagu: :)

kagu: jah tore

truggy: suht ei ole vaikus hetkel

truggy: on vaiksemaidki hetki siin olnd

snow: jaja mida iganes

snow: mis te siis r22gite

snow: ka

kagu: ei tea pole sin enne käinud

truggy: rääkida võib kõigest, enam vähem :P

kagu: tore

truggy: jaaa

truggy: mis teoksil teil ka?

kagu: millest te siin räägite ka?

truggy: pmst siin räägitakse kõikidel teemadel üldiselt :P (JT)

Lauses (14) tekitatakse selge vastandus SCripti kirjutatule ja põhimõtteliselt kasutatakse siduva sõnana. modegirl alustab vooru diskursusemarkeriga selleks, et pöörduda tagasi eelneva vaidluse juurde. Laiemast kontekstist jääb selgusetuks, kas modegirl on kohtumõistja või vaidluses osaleja. modegirl ründab SCripti, kasutades selleks käibefraasi (vanematega ei vaielda). Tegemist on pöördega diskursuses, kus eelnev kontekst seostatakse järgnevaga ehk modegirl seob diskursusemarkeri põhimõtselt abil teise inimese vooru enda omaga.

(14) plika_tartust: script palun suundu istmikusse j22karupoeg: tubli tubli :P

citty: ei ei ei sul asjast täitsa vale arusaam ikka sina oled modegirl: < plika_tartust $>$ script palun suundu istmikusse $<<$ vapsee viisakas

SCript: hahaaaaa targem annab järele järelikult oled sina

SCript: hihiiii

SCript: =)

SCript: vot nii 
Henry: tre

modegirl: põhimõtselt, SCript, vanematega ei vaielda, seega ole tasa

(JT)

Viimastes näidetes on toodud juhtumid, kus põhimõtteliselt on võimalik lausest välja jätta, ilma et üksiklause tasandil miski muutuks, s.h lause propositsioon teiseneks. Kui lausetest (10), (12), (13), (14) jätta põhimõtteliselt välja, siis lause üldine struktuur ei muutuks, kuid lause kaotaks nüansse pragmaatilisest vaatepunktist. Põhimõtteliselt on aga lausetesse lisatud põhjusega ning sõna täidab nendes kontekstides kindlat funktsiooni.

Eelnevas on näidatud sõna kujunemislugu viimase sajandi jooksul, kusjuures välja on toodud areng adverbist pragmaatiliseks markeriks. Nende üksuste viisimääruslikule kasutusele on lisandunud määramääruslik nüanss. Sellist üksust on võimalik interpreteerida samal ajal modaalpartikliks. Samas on välja kujunenud ka diskursuseülene funktsioon, muutes üksuse veelgi abstraktsemaks. Muutus konkreetsest adverbiks abstraktseks markeriks on tüüpiline kujunemisahel, mida on välja toodud ka teiste keelte näitel (vt Traugott, Dasher 2002).

\section{Praktiliselt}

Praktiliselt, nagu ka põhimõtteliselt, on sõna, mis pärineb tuletatud adjektiivist ehk sõnast praktiline. F. J. Wiedemanni eesti-saksa sõnaraamatus leidub adjektiiv kujul praktiline : praktilise (Wiedemann 1923 [1869]). Praktiliselt tähendab 'tegelikkuses, praktikas' ja võib olla sünonüümne sõnaga otstarbekalt. Korpuses on sõna esmakordselt 1900. aastate tekstides. Kuigi esinemissagedus on väike, näitab materjal, et 20. sajandi esimesel poolel kasutatakse seda vaid viisiadverbina (Valdmets 2010: 32). Nagu ka sõna põhimõtteliselt puhul, on konkreetseid arvandmeid praktiliselt kohta kasutatud vaid taustinformatsioonina ja keskendutakse pigem kvalitatiivsele analüüsile. Olgu aga siinkohal välja toodud, et alles 20. sajandi teisel poolel on võimalik sõna praktiliselt leida uues ehk pragmaatilises funktsioonis. 1960. aastatel esineb see esimest korda ka ilukirjanduses, sinnamaani tuli see välja vaid korpuse ajakirjandustekstides.

Praktiliselt esineb esmakordselt 1900. aastatel vaid ühes näitelauses, kus see on kasutusel viisiadverbina (15). 1930. aastate korpuses leidub teinegi üksik ajakirjandusest pärit täistähenduslik kasutus (16). Sajandi esimesel poolel on sõna kasutusel vaid adverbina, esitatud näide (17) on pärit 1950. aastatest.

(15) Rahwaid näemegi selle kallal nägeliselt (teorialiselt) ja tegeliselt (praktiliselt) tööl olema. (AJA1900)

(16) Sinagi lahkelt tunnustad, et mu selged teoreetilised vahetegemised olevat kenad lugeda - aitäh sellegi eest! - kuid väidad, et ma praktiliselt, laval ajan asjad untsu. (AJA1930)

(17) 32 valla- ja külanõukogu täitevkomitee sekretäri Viru-, Harju-, Lääne- ja Hiiumaalt sõitis tagasi oma kodukohtadesse, et praktiliselt rakendada omandatud teadmisi täitevkomitee igapäevases töös. (AJA1950) 
Edaspidi kirjeldatakse sõna modaalseid kasutusjuhte. Modaalne tarvitus ilmneb 20. sajandi teisel poolel. Arvestades aga vähest esinemissagedust korpuses (1900. ja 1930. aastatel ühes lauses, 1950. aastatel viies lauses ja 1960. aastatel 14 lauses), ei saa kaugeleulatuvaid järeldusi teha. Kuigi üldine kasutussagedus korpuses suureneb aasta-aastalt, ei esine see sõna korpuses kuni 21. sajandi alguseni kuigi tihti (sarnane tendents keelendiga põhimõtteliselt, täpseid arvandmeid vt Valdmets 2010: 32). ${ }^{4}$ Kõnelähedasemas kirjakeeles ehk jututubade materjalis on praktiliselt siiski sagedamini esindatud. Samas on toodud taas uuema aja andmed.

Alustame paari näitega modaalpartiklilisest kasutusest. Lausetes (18), (19) ja (20) on praktiliselt loetud partiklite hulka, kuid modaalsus ei ole siinkohal alati läbinähtav. Pigem märgib selline kasutus nihet algsest täistähenduslikust kasutusest eemale, nii et praktiliselt funktsioneerib uues ümbruses fraasi- või lauselaiendina. On öeldud, et praktiliselt kui modaalne üldlaiend kipub tänapäevases keelekasutuses välja tõrjuma modaalsõnu tegelikult, õigupoolest, peaaegu, enam-vähem (Erelt 2006: 74).

Lausetes (18) ja (19) on sõna kasutatud fraasilaiendina. Näites (18) asetub praktiliselt küll lause algusesse, kuid siin ei seostu see diskursusega (täpsemalt vt Valdmets 2013), üksus funktsioneerib sõna kõik laiendina, ${ }^{5}$ näidates, et enamvähem kõigis sadamates on töö katkenud. Samamoodi nagu lausetes (19) ja (20), on ka näites (18) esile tõstetud sõna, mille tähendus on nihkunud pragmaatilisema kasutuse suunas ning mida enam ei saa interpreteerida kui üksust, mis näitab asja olemust tegelikkuses või praktikas nagu näidete (15), (16) ja (17) korral. Tegemist on pigem metafoorse kasutusega, mis ilmselt tundub keelekasutajale ilmekam. Praktiliselt omandab lõpuks sama funktsiooni, nagu on sõnadel peaaegu või enam-vähem. Ka näitelauses (19) asetub modaalpartikkel fraasi algusesse (praktiliselt ainukene koht). Lauses (20) kuulub praktiliselt pigem verbifraasi, asetudes verbi ette. Siiski leidub korpuses ka selliseid juhtumeid, kus praktiliselt paikneb pärast verbi. Enamasti asetuvad partiklid aga peasõna vahetusse lähedusse. See on tüüpiline ka teiste pehmendajate puhul. Lauses (21) on praktiliselt episteemiline partikkel, vt arutlust näite (9) juures.

(18) Praktiliselt kõigis Inglise sadamates on töö katkenud. (AJA1970)

(19) Talvistel aegadel on trepikoda praktiliselt ainukene koht, kus saab magada rahus ja vaikuses. (ILU1990)

(20) Ometi üle rahvuspiiride minevad kontaktid praktiliselt puuduvad. (AJA1990)

(21) - Kas sa linna vahel ka kuskil liigud?

- Praktiliselt ei. (EE1996)

Lisaks modaalpartiklilaadsetele juhtudele leiab sõna praktiliselt ka diskursusemarkeri kasutust, millele näites (22) viitab lausealguline positsioon ning funktsioneerimine diskursuse korraldajana ehk lauseteülese üksusena. Sõna tähenduski on juba nihkunud, kuid süntaktiliselt ei ole see veel vabalt liikuv liige. Küsimus käib 11. septembril 2001 toimunud terrorirünnaku kohta. Lugeja EditX esitab küsimuse ning laiendab seda kohe järgneva lausega. Siinkohal funktsioneerib praktiliselt õigustusena eelnevalt öeldule. See täpsustab eelnevalt öeldut, samal ajal küsimust

4 Sõna praktiliselt kasutussagedus 100000 sõna kohta on esimesel esinemisel kirjakeele korpuses (1900. aastatel) 
lahti mõtestades või parandades. Siiski pole see täielikult väljakujunenud diskursusemarker, kuna sõna süntaktiline käitumine on veel muutumata, st normaallause ehitust silmas pidades poleks võimalik praktiliselt siinsest lausest välja jätta (Kuidas on võimalik, et USA meedia on nii halvasti informeeritud sündmuste käigust, ohvrite arvust jms? ${ }^{*}$ Ketras USA meedia eile terve päeva jooksul samu kaadreid ja kordas samu tsitaate...). Nimelt on praktiliselt lauses esimesel kohal, seejärel tuleb verb ning alles siis järgneb subjekt. Iseseisva diskursusemarkeri puhul oleks tavapärasem teises lauses sõnade järjekord USA meedia ketras... Seega on praktiliselt näites (22) kujunemisjärgus diskursusemarker.

(22) EditX, 15:34 12.09.2001: Kuidas on võimalik, et USA meedia on nii halvasti informeeritud sündmuste käigust, ohvrite arvust jms? Praktiliselt ketras USA meedia eile terve päeva jooksul samu kaadreid ja kordas samu tsitaate, mis olid kõigil juba pähe kulunud? (EPL2001)

Näidetes (23) ja (24) funktsioneerib praktiliselt samuti diskursusemarkerina, kuid siin on kasutusel juba väljakujunenud üksus. Nendes lausetes on sõna järgnevaga vaid nõrgalt seotud ning üksus asub väljaspool lause süntaktilist struktuuri. Kui see lause algusest välja jätta, oleks süntaktiliselt määratav siiski tavapärane lauseehitus.

(23) "Ega sellisest sitasest mersust rohkem välja ei pigistagi!" "Võibolla ütlete, et seisite lausa paigal?” küsib GAI-mees.

"Praktiliselt ma seisingi paigal," kinnitab mersujuht.

"Sellisel juhul viiskümmend dollarit keelatud kohas parkimise eest!" (EE1997)

(24) "Innar Mändoja kannatas tänase etapi poolhaigena lihtsalt lõpuni. Järgmisest etapist jääb meid alles ainult viis meest, nii et liidrisärgi hoidmine saab raske olema. Praktiliselt suurt sõnaõigust meil enam ei ole.” (EPL2001)

Praktiliselt on lauses (23) kui abivahend, mis aitab vooru alustada. Kuna eelnev on üldküsimus, siis eeldatav vastus on jaatus või eitus. Praktiliselt näitab kohe vooru alguses, et vastus on modifitseeritud. Seega võib diskursusemarkeri kasutuses märgata marginaalset modaalsust, kuna mersujuhi vastus dialoogis näitab, et vastaja ei aktsepteeri küsimust tingimusteta ja vaidleb selle proportsioonile vastu (küsimus on selgelt irooniline ning esitab paigalseisu versiooni kui ilmvõimatut).

Näites (24) on tegu sama autori kahe järjestikuse lausega, kusjuures praktiliselt on siin lausete liigendaja diskursuses. See aitab luua suuremaid infolõike, kusjuures praktiliselt ei seostu siinkohal ainult vahetult eelneva lausega, vaid kogu tsitaadiga, ja selge on ka sõna kokkuvõttev funktsioon (vt ka näidet (13) põhimõtteliselt juures). Tegemist on kas autori tehtud pöördega monoloogis, kus püütakse eelnevalt öeldut leevendada, või siis jäetakse väide veel mõneti lahtiseks.

Nagu põhimõtteliselt, võib ka praktiliselt esineda toimetamata kirjakeeles lühenenult, kui kirjutaja soovib matkida kõnekeelset vormi. Nii saab praktiliselt olla kujul praktselt, prakselt vms. Sellised vormid on oma funktsioonilt sarnased eelnevalt kirjeldatud pragmaatiliste markeritega.

Järgnevates näidetes jututubade korpusest (25) ja (26) on esindatud mõlemad artiklis uuritavad üksused küll erinevates kontekstides ja erinevate inimeste kirjutatuna, kuid sarnases funktsioonis ja positsioonis. Sellised pragmaatilised markerid näitavad tõenäoliselt, et nende kasutajad määravad oma elukoha või 
päritolu geograafiliselt mingi linna tasemel, kuid siis umbmäärastavad selle väite modaalpartikli abil. Teine seletus võiks olla ajalise määratluse umbmäärastamine. Mõlema seletuse järgi on sõna semantiliselt analüüsitav modaalpartikliks, mida saaks tõlgendada tähenduses 'enam-vähem' või ‘enamasti, enamjaolt'.

(25) La_Femme_Nikita: -+heigo18+- kus elad?????

[---]

Heigo18: M;a elan Paides praktiliselt! (JT)

(26) msn_muzy_13: sa paidest we

kissy: sirtz ma trtust

muru: ma ka põhimõtteliselt (JT)

Siinkohal on partiklitel samasugune funktsioon nagu voorulõpulisel üksusel põhimõtteliselt näites (10) eespool. Nii kasutaja Heigo18 kui ka muru vastavad endale esitatud küsimusele. Näide (25) on vaid täislause, mis on vastuseks konkreetsele eriküsilausele. Näites (26) lõpetatakse sõnaga põhimõtteliselt voor, mis ilmselt vastab valikküsilausele. Siinses näites on täheldatav lünklause ( $m a$ ka põhimõtteliselt), kust paraku ei selgu, kas tegemist on reageeringuga kasutajale msn_muzy_13 või kissy. Ümbritsev laiem kontekst ei loo samuti selgust, kuna rohkete osalejatega vestluses tekib konkreetse vestluse raames palju ebakõla, mis omakorda viib jututoa kasutajate ärrituse ning ropendamiseni. Sellegipoolest saab siinkohal määrata sõna põhimõtteliselt modaalseks (vt ka sõna põhimõtteliselt analüüsi näites (9)).

Selliseid otseseid kattumisi põhimõtteliselt ja praktiliselt funktsioonide vahel võib korpusest leida veelgi. Seetõttu võib märkida, et mõlemad sõnad on teatud kontekstides võrdväärsed ja seetõttu ka vahetatavad.

Võttes arvesse semantikat-pragmaatikat, süntaksit ja foneetikat, on võimalik esitada mõned tähelepanekud sõnade kujunemise kohta. Algsest adverbilisest funktsioonist on esmajärgus välja arenenud üksuste modaalpartikliline kasutus, kus fraasi-ja lauselaiendid on lausungisiseselt tekstiga seotud. See kajastab sõnade umbmäärastavat funktsiooni. Kuna aga semantiliselt on nihe juba toimunud, siis edasine areng puudutabki tõenäoliselt sõnu, mis esmajärgus on küll oma täistähenduse juba minetanud, kuid süntaktiliselt võivad veel olla lausega seotud. Järgmine arenguaste puudutab markereid, mis funktsioneerivad diskursuseüleselt ega ole konkreetse lausega, mida nad alustavad, otseselt seotud. Sõna lühenenud kuju viitab kindlasti pragmaatilisele funktsioonile, kus adverbiline interpretatsioon enam võimalik ei ole.

Põhimõtteliselt ja praktiliselt on sõnad, mis on liikumas otsese tähendusega kasutusest pragmaatilise suunas. Kui praktiliselt erinevad tähendused on seletavas sõnaraamatus fikseeritud, siis sõnaartikli põhimõtteliselt juures on seal nimetatud vaid üks tähendus ('põhimõtetelt, põhimõtte poolest; põhimõtte pärast'). Samas tuleb tõdeda, et mõned kasutusnäited paistavad siiski illustreerivat pragmaatilist kasutust, nt Meie olukorrad on põhimõtteliselt sarnased (EKSS). Eeldades, et nende kahe sõna arengusuund on sarnane teiste grammatiseeruvate adverbidega maailma keeltes, võime näha, kuidas neid kasutatakse tänapäeval sagedasti just pragmaatilises funktsioonis. Arvestades grammatisatsiooni mehhanisme, võib eeldada, et aja jooksul üksuse lähtefunktsioon kaob ja alles jääb vaid sihtfunktsioon. Samas on tõdetud (Heine 1993: 48-49, Hopper, Traugott 2003: 49, 124-125), et paralleelne eksisteerimine võib kesta sadu aastaid ning kõik grammatiseeruvad üksused ei jõua 
selleni, et mingi funktsioon täielikult kaoks. Ennustavalt võib arutleda selle üle, mis saab siis, kui artiklis uuritud sõnade lähtefunktsioon peaks ühel hetkel kaduma. Tõenäoline on, et sellisel juhul asendab keelekasutaja selle teise vormiga, mõne muu üksusega või kaob sootuks vajadus selle konkreetse sõna järele.

\section{Kokkuvõte}

Põhimõtteliselt ja praktiliselt on kujunemisjärgus üksused, mille algne kasutus hakkas mingil ajaperioodil (kirjakeele korpuse andmetel vastavalt 1930. ja 1960. aastatel) muutuma ning täistähenduslikule adverbilisele tarvitusele on lisandunud uusi, pragmaatilisi funktsioone. Seega ilmneb korpusematerjali põhjal, et keeles eksisteerivad kõrvuti nii adverbiline kui ka pragmaatiline tarvitus. Selle tõestuseks on artiklis esitatud nii süntaktilisi, semantilis-pragmaatilisi kui ka foneetilisi fakte.

Artiklis näidati, kuidas nimetatud üksused on kirjakeeles kasutusel kahes erinevas põhifunktsioonis: adverbilises ja pragmaatilises. Korpusematerjalile tuginedes kirjeldati pragmaatiliste üksuste edasist jagunemist modaalpartikliteks ja diskursusemarkeriteks. Kui enamjaolt arenevad lt-liitelised adverbid eesti keeles episteemilisteks partikliteks (vt nt Valdmets 2013 sõnade lihtsalt, tegelikult, ilmselt ja loomulikult kohta), siis põhimõtteliselt ja praktiliselt on erilised, kuna nende üheks funktsiooniks partiklina on umbmäärastamine (põhimõtteliselt kõik, praktiliselt pool). Selliseid fraasilaiendeid kasutatakse sageli kirjalikus diskursuses, kuid eeldatud on, et kirjalik eesti keel on mõjutatud suulisest eesti keelest. Seetõttu kaasati artiklisse näiteid ka kõnelähedasest kirjakeelest (interneti jututubadest).

Põhimõtteliselt ja praktiliselt on oma adverbilises kasutuses kaks erinevat leksikaalset üksust, mille semantiline väli ei kattu. Eesti kirjakeele korpuse põhjal on aga võimalik leida näiteid pragmaatilise kasutuse kohta, kus uuritavad üksused funktsioneerivad sarnaselt. Foneetiliselt on võimalik välja tuua mõlema üksuse lühenenud kuju kõnelähedases kirjakeeles. Süntaktiliselt on määratletavad üksused, mis adverbina on kindlalt lausega (verbiga) seotud. Adverbiaalina kasutatakse neid sõnu rõhulises positsioonis, kusjuures neile on võimalik lisada laiendeid. Kui sõna omandab uusi funktsioone pragmaatilise markerina, siis esmajärgus (süntaksist lähtuvalt) on see veel mõnevõrra seotud ülejäänud lausega, kuid sellisel juhul esineb see enamasti rõhutus positsioonis. Siinkohal on mõeldud sildkontekste, kus modaalpartiklid käituvad üldlaienditena, $\mathrm{mh}$ ka pehmendajatena (kindel positsioon peasõna vahetus läheduses) ja diskursusemarkerid paiknevad lause alguses, neile järgneb verb ning seejärel subjekt. Lauses vabalt liikuvad üksused on siinse käsitluse järgi sõnad, mida on võimalik diskursusest hõlpsalt välja jätta ilma propositsiooni muutuseta. Tegu on üksustega, millel on peamiselt diskursuseülene kasutus ja teksti liigendav funktsioon.

Semantiliselt on adverbid täistähenduslikud ning konkreetse sisuga, mida on kerge ka kontekstiväliselt määratleda. Samuti on adverbid küsimustatavad. Semantilisest-pragmaatilisest vaatepunktist on põhimõtteliselt ja praktiliselt järgmine arenguaste vaheetapp, kus algne adverbiline tähendus on veel mõneti tajutav, kuid tegelikult on võimalik näha ka uut, pragmaatilist funktsiooni. Edasise arengu käigus "täieõiguslikuks" modaalpartikliks või diskursusemarkeriks täistähendus taandub. Keelendite muutumise tulemuseks on abstraktsed hägusa tähendusega üksused, 
mida pole võimalik küsimustada ega leksikaalse üksusena tõlgendada. Kõike eelnevalt arvesse võttes võib esitada grammatisatsiooniahela, kus pragmaatilised markerid on pärit adverbilisest lähtest, kusjuures diskursusemarkeri funktsioon on rohkem grammatiseerunud kui modaalpartikli oma.

Kokkuvõtvalt võib öelda, et põhimõtteliselt ja praktiliselt on oma leksikaalselt lähtelt erinevad, kuid grammatiliselt arengukäigult sarnased üksused. Kuniks inimestel on vajadus oma väiteid ähmastada, selline pragmaatiliste üksuste areng ka jätkub. Seda tüüpi tugevdavatel ja pehmendavatel üksustel on eri keeltes kalduvus kiiresti vahetuda ning muutuda, mida ka artiklis käsitletud moesõnad ilmekalt näitavad.

\section{Lühendid}

$\begin{array}{ll}\text { EE } & \text { Eesti Ekspress } \\ \text { EPL } & \text { Eesti Päevaleht } \\ \text { ET2002 } & \text { Emil Tode 2002, Raadio } \\ \text { ILU } & \text { ilukirjandus } \\ \text { JT } & \text { jututoad } \\ \text { KR } & \text { seltskonnaajakiri Kroonika } \\ \text { OR2002 } & \text { Olev Remsu 2002, Kevad Hiinas } \\ \text { S } & \text { subjekt } \\ \text { V } & \text { verb } \\ \text { X } & \text { objekt, adverbiaal, predikatiiv }\end{array}$

\section{Viidatud kirjandus}

Aijmer, Karin 1997. I think - An English Modal Particle. - Toril Swan, Olaf Jansen Westvik (Eds.). Modality in Germanic Languages. Historical and Comparative Perspectives. New York: Mouton De Gruyter, 1-47. http://dx.doi.org/10.1515/9783110889932.1

Aijmer, Karin 2013. Understanding Pragmatic Markers. A Variational Pragmatic Approach. Edinburgh: Edinburgh University Press Ltd.

Beeching, Kate; Detges, Ulrich (Eds.) (ilmumas). The Role of the Left and Right Periphery in Semantic Change. Amsterdam: Benjamins.

Biber, Douglas; Johansson, Stig; Leech, Geoffrey; Conrad, Susan; Finegan, Edward 2007 [1999]. Longman Grammar of Spoken and Written English. Kuues parandatud trükk. Pearson Education Limited.

Brinton, Laurel J. 1996. Pragmatic Markers in English. Grammaticalization and Discourse Functions. Berlin/New York: Mouton de Gruyter. http://dx.doi. org/10.1515/9783110907582

Brinton, Laurel J. 2010. Discourse Markers. - Andreas H. Jucker, Irma Taavitsainen (Eds.). Historical Pragmatics. Handbooks of Pragmatics 8. Berlin/New York: Mouton de Gruyter, 285-314.

Brinton, Laurel J.; Traugott, Elizabeth Closs 2005. Lexicalization and Language Change. Cambridge: Cambridge University Press. http://dx.doi.org/10.1017/CBO9780511615962

Bybee, Joan L. 2003. Mechanisms of change in grammaticization: The role of frequency. Brian D. Joseph, Richard D. Janda (Eds.). The Handbook of Historical Linguistics. Oxford: Blackwell, 602-623. http://dx.doi.org/10.1002/9780470756393.ch19

Erelt, Mati 1986. Eesti adjektiivisüntaks. [The Syntax of Estonian Adjectives.] Tallinn: Valgus.

Erelt, Mati 2006. Lause õigekeelsus. Juhatused ja harjutused. [Sentence Norms. Instructions and Exercises.] Tartu.

Fraser, Bruce 1996. Pragmatic Markers. - Pragmatics, 6 (2), 167-190. 
Hansen, Maj-Britt Mosegaard 1997. Alors and donc in Spoken French: A reanalysis. - Journal of Pragmatics, 28 (2), 153-187. http://dx.doi.org/10.1016/So378-2166(96)ooo86-o

Heine, Bernd 1993. Auxiliaries. Cognitive Forces and Grammaticalization. New York/Oxford: Oxford University Press.

Heine, Bernd 2002. On the role of context in grammaticalization. - Ilse Wischer, Gabriele Diewald (Eds.). New Reflections on Grammaticalization. Typological Studies in Language 49. Amsterdam/Philadelphia: Benjamins, 83-101. http://dx.doi.org/10.1075/ tsl.49

Heine, Bernd; Narrog, Heiko 2010. Grammaticalization and linguistic analysis. - Bernd Heine, Heiko Narrog (Eds.). The Oxford Handbook of Linguistic Analysis. New York: Oxford University Press, 401-423.

Hopper, Paul J. 1991. On some principles of grammaticization. - Elizabeth Closs Traugott, Bernd Heine (Eds.). Approaches to Grammaticalization, Vol. I. Typological Studies in Language 19:1. Amsterdam: John Benjamins, 17-36. http://dx.doi.org/10.1075/tsl.19.1

Hopper, Paul J. 1998. Emergent grammar. - Michael Tomasello (Ed.). The New Psychology of Language. Cognitive and Functional Approaches to Language Structure. Mahwah, NJ: Lawrence Erlbaum Associates, 155-175.

Hopper, Paul J.; Traugott, Elizabeth Closs 2003. Grammaticalization. Second edition. Cambridge: Cambridge University Press. http://dx.doi.org/10.1017/CBO9781139165525

Huumo, Tuomas 1995. On the position of subject in Finnish and Estonian. - R. Kataja, K. Suikkari (Toim.). XXI kielitieteen päivät Oulussa 6.-7.5.1994. Acta Universitatis Ouluensis, series B Humaniora 19. Oulu, 79-87.

Kaivapalu, Annekatrin 2010. Mõnede eesti sõnajärjemallide psühholingvistilisest reaalsusest. [On psycholinguistic reality of some word order patterns of Estonian.] - Eesti Rakenduslingvistika Ühingu aastaraamat, 6, 103-120. http://dx.doi.org/10.5128/ ERYa6.07

Keevallik, Leelo 2003. From Interaction to Grammar: Estonian Finite Verb Forms in Conversation. Studia Uralica Upsaliensia 34. Uppsala.

Kilgi, Annika; Ross, Kristiina 2006. Lühike sissejuhatus eesti keelde 1732. Saksa keelest tõlkinud ja järelsõnad kirjutanud Annika Kilgi ja Kristiina Ross. [A short introduction to Estonian 1732. Translation from German and epilogue by Annika Kilgi and Kristiina Ross.] Tallinn: Eesti Keele Sihtasutus.

Kingisepp, Valve-Liivi; Ress, Kristel; Tafenau, Kai 2010. Heinrich Gösekeni grammatika ja sõnastik 350. [The grammar and dictionary of Heinrich Göseken 350.] Tartu: Tartu Ülikooli eesti ja üldkeeleteaduse instituut.

Lindström, Liina 2005. Finiitverbi asend lauses. Sõnajärg ja seda mõjutavad tegurid suulises eesti keeles. [The position of the finite verb in a clause: word order and the factors affecting it in Spoken Estonian.] Dissertationes philologiae estonicae Universitatis Tartuensis 16. Tartu: Tartu Ülikooli Kirjastus.

Quirk, Randolph; Greenbaum, Sidney; Leech, Geoffrey; Svartvik, Jan 1985. A Comprehensive Grammar of the English Language. London, NY: Longman.

Schourup, Lawrence 1999. Discourse markers. - Lingua, 107 (3-4), 227-265. http://dx.doi. org/10.1016/Soo24-3841(96)90026-1

Tael, Kaja 1988. Sõnajärjemallid eesti keeles (võrrelduna soome keelega). [Estonian word order patterns (compared to Finnish).] Preprint KKI-56. Tallinn: Eesti NSV Teaduste Akadeemia Keele ja Kirjanduse Instituut.

Traugott, Elizabeth Closs 2007. Discourse markers, modal particles, and contrastive analysis, synchronic and diachronic. - Catalan Journal of Linguistics, 6, 139-157. 
Traugott, Elizabeth Closs 2012. Intersubjectification and clause periphery. Intersections of Intersubjectivity. - Lieselotte Brems, Lobke Ghesquière, Freek Van de Velde (Eds.). Special Issue of English Text Construction, 5 (1), 7-28. http://dx.doi.org/10.1075/ etc.5.1

Traugott, Elizabeth Closs; Dasher, Richard B. 2002. Regularity in Semantic Change. Cambridge: Cambridge University Press.

Valdmets, Annika 2010. Mõne modaalpartikli kujunemine ja kasutamine eesti kirjakeeles alates 1890. aastatest. [The development and use of some of the modal particles of written Estonian since the 1890's.] Magistritöö. Käsikiri Tartu Ülikooli eesti keele õppetoolis.

Valdmets, Annika 2013. Modal particles, discourse markers, and adverbs with lt-suffix in Estonian. - Liesbeth Degand, Bert Cornillie, Paola Pietrandrea (Eds.). Discourse Markers and Modal Particles. Categorization and Description. Pragmatics \& Beyond New Series 234. Amsterdam: John Benjamins, 107-132. http://dx.doi.org/10.1075/ pbns.234

Valdmets, Annika; Habicht, Külli 2013. Episteemilistest modaalpartiklitest eesti kirjakeeles. [About epistemic modal particles in Estonian.] - Teoreetilisest keeleteadusest Eestis III. Ilona Tragel, Ann Veismann, Piret Piiroja (Toim.). Eesti ja soome-ugri keeleteaduse ajakiri ESUKA, 4 (1), 205-222.

Van der Wouden, Ton; Foolen, Ad 2011. Dutch Particles in the Right Periphery. http://www. tonvanderwouden.nl/index_files/papers/fipa-2011-05b.pdf (16.12.2013).

Wiedemann, Ferdinand Johann 1923 [1869]. Estnisch-deutsches Wörterbuch: mit einer Karte Eestis. Kolmas, muutmata trükk. Tartu: Eesti Kirjanduse Selts.

\section{Võrgumaterjalid}

EKSS = Eesti keele seletav sõnaraamat. http://www.eki.ee/dict/ekss/ (9.12.2013).

Eesti kirjakeele korpus. http://www.cl.ut.ee/korpused/kasutajaliides/ (27.7.2013).

Tasakaalus korpus. http://www.cl.ut.ee/korpused/grammatikaliides/ (27.7.2013).

Annika Küngas (Tartu Ülikool), peamine uurimisvaldkond on eesti kirjakeele pragmaatiliste markerite kujunemine ja kasutamine. Jakobi 2, 51014 Tartu, Eesti annika.kungas@ut.ee 


\title{
PÕHIMÕTTELISELT OR PRAKTILISELT IN PAIDE - TWO WORDS WITH SIMILAR FUNCTIONS
}

\author{
Annika Küngas \\ University of Tartu
}

This article offers a corpus-based overview of two Estonian words, namely põhimõtteliselt 'in principle; basically' and praktiliselt 'practically; virtually', illustrating their development and use mostly during the last hundred years. These two items may have various functions in the language. Used as adverbs, põhimõtteliselt and praktiliselt are words with different lexical fields. However, both words have undergone grammaticalization, as a result of which their functions have become similar. They are used more and more as pragmatic markers and therefore have developed from full-content adverbs into abstract items. As pragmatic words, they occur as modal particles or discourse markers. Therefore, they are mainly seen as downtoners or words that make the discourse more coherent. The data show that there have been changes in the way that these two words are used semantically, as well as syntactically and phonetically. Phonetically, these items are losing their lexical content; but this kind of erosion is only present with pragmatical uses. Syntactically, when used as adverbs, these words are bound to the sentence. They are stressed items that may get a modifier on their own. As pragmatic markers, these items are only loosely attached to the nearby discourse or not at all. Semantically, as grammaticalized words, põhimõtteliselt and praktiliselt have become fuzzier: now they are seen as words that have an abstract meaning while they are used as sentence or phrase modifiers. Alternatively, they may function on the discourse level to structure the text.

Keywords: pragmatic markers, adverbs, written language, corpus research, Estonian 